\title{
Nutritional Care of the Older Patient with Fragility Fracture: Opportunities for Systematised, Interdisciplinary Approaches Across Acute Care, Rehabilitation and Secondary Prevention Settings
}

\author{
Jack J. Bell, Ólöf Guðný Geirsdóttir, Karen Hertz, \\ Julie Santy-Tomlinson, Sigrún Sunna Skúladóttir, \\ Stefano Eleuteri, and Antony Johansen
}

\footnotetext{
This chapter is a component of Part 5: Cross-cutting Issues.

For an explanation of the grouping of chapters in this book, please see Chapter 1: 'The multidisciplinary approach to fragility fractures around the world—an overview'.
}

\author{
J. J. Bell (ه) \\ The Prince Charles Hospital and School of Human Movement and Nutrition Sciences, \\ University of Queensland, St Lucia, QLD, Australia \\ e-mail: Jack.Bell@health.qld.gov.au \\ Ó. G. Geirsdóttir · S. S. Skúladóttir \\ Faculty of Food Science and Nutrition, School of Health, University of Iceland, \\ Reykjavík, Iceland \\ e-mail: ogg@hi.is \\ K. Hertz \\ Royal Stoke University Hospital, Stoke-on-Trent, UK \\ e-mail: karen.hertz@uhns.nhs.uk \\ J. Santy-Tomlinson \\ Orthopaedic Nursing, Odense University Hospitals/University of Southern Denmark, \\ Odense, Denmark \\ e-mail: juliesanty@tomlinson15.karoo.co.uk

\section{S. Eleuteri} \\ Department of Psychology, Sapienza University of Rome A, Rome, Italy \\ e-mail: stefano.eleuteri@uniroma1.it
}

\section{A. Johansen}

Trauma Unit, University Hospital of Wales, Cardiff, UK

National Hip Fracture Database, Royal College of Physicians, London, UK e-mail: antony.johansen@wales.nhs.uk 


\subsection{Background}

Increasing numbers of fragility fractures in ageing populations represent a substantial and significant pressure on patients, carers, healthcare systems and societies around the world [1]. Frail older people with fragility fractures require comprehensive, orthogeriatric care [2]. Co-existing chronic diseases confound acute interventions and efforts to improve recovery in rehabilitation, and have a negative impact on patient outcomes, long-term survival and quality of life.

An interdisciplinary approach to the management of the presenting fracture and pre-existing co-morbidities will improve outcomes. Preventing future fractures and additional harmful diagnoses should also be a priority for treating teams in the acute, rehabilitation and secondary prevention settings [1]. Individualised care is a core component of orthogeriatric care. However, this must be underpinned by interdisciplinary actions and systems that support timely and appropriate delivery of care.

Nutrition-related diagnoses are key predictors of initial and secondary fragility fractures and are among the most harmful co-morbidities in older orthopaedic patients across acute, rehabilitation and community settings. Nutrition interventions are core components of primary and secondary fracture prevention and have been shown to improve outcomes in the acute and rehabilitation settings.

Many models of nutrition care focus on highly individualised assessments and interventions provided by dietitians or medical nutrition specialists [3]. The high prevalence of protein-energy malnutrition and other nutrition-related diagnoses is well described across many orthogeriatric settings, and there are strong associations between nutrition-related diagnoses and patient and healthcare outcomes. Despite this, in many orthopaedic settings timely access to specialist clinical nutrition care is limited or absent [4]. Increases in diagnosis and referral rates, patient complexity, healthcare costs and service demands, combined with reduced lengths of stay and unsustainable health expenditure growth, suggest that it will not be possible to provide all patients identified at risk of a nutrition-related diagnosis with individual access to specialist nutrition services [3]. This chapter therefore presents a call to action. Systematised, interdisciplinary nutrition care actions are urgently required across the pillars of acute care, rehabilitation and secondary fracture prevention [1].

\subsection{SIMPLE or Specialised Nutrition Care?}

Models in which interdisciplinary healthcare workers provide early, supportive nutrition care across the three pillars may be best placed to deliver high value nutrition support. Such models include the Systematised, Interdisciplinary Malnutrition Program for impLementation and Evaluation (SIMPLE), the More-2-Eat program and a multidisciplinary, multimodal nutrition care model applied in hip fracture by Bell et al. $[3,5,6]$. These models suggest that patients are triaged into three groups: those not at risk and appropriate for standard care, those who are at risk or malnourished but do not require specialised nutrition care and those who are likely to benefit from a nutrition care specialist. 


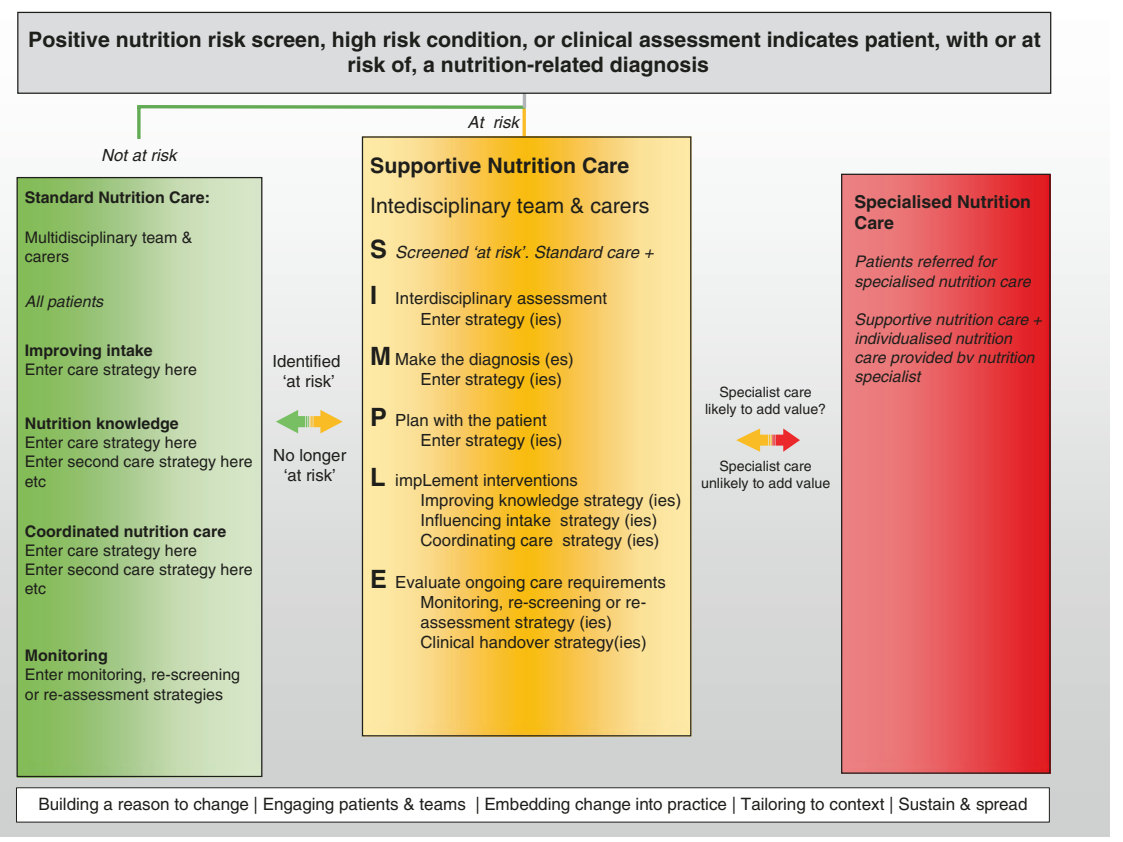

Fig. 18.1 Nutritional care of the older patient with fragility fracture

These models have focused on implementing nutrition care in the acute setting for patients with, or at risk of, protein-energy malnutrition. This has included the use of action reflection cycles to collect relevant data justifying change, then progressively developing, implementing, evaluating and iteratively improving chosen nutrition care activities [7, 8].

Figure 18.1 provides a SIMPLE illustration of how to support nutrition care of the older patient with fragility fracture. This is considerate of key nutrition care models internationally [3,5,9-11], and supports different members of orthogeriatric teams to contribute to systematised, interdisciplinary nutrition care for patients with, or at risk of a nutrition-related diagnosis, globally.

Specific strategies have not been identified, so that local teams can tailor the approach across a variety of nutrition-related diagnoses, frameworks and contexts. Systematised and interdisciplinary care nutrition actions are encouraged, but local processes should still inform referral for specialist nutrition advice when this is likely to add value. Conversely, if referral is unlikely to add value, for example when ongoing specialist intervention is unlikely to add benefit or improve what matters to the patient, supportive nutrition care should be the priority $[12,13]$.

The underlying themes along the bottom of the model highlight that successful and sustained nutrition care requires the engagement of local patients and teams using a knowledge translation approach; a 'cut and paste' approach to process changes will not yield the same outcomes [7, 11, 14]. 


\subsection{Screening for Nutrition Risk (SIMPLE)}

Nutritional risk increases substantially with age, multimorbidity and fragility fracture, and screening and/or assessment should be routine across orthopaedic settings. A two-step approach, with 'first pass' nutrition screening, followed by a detailed assessment by a qualified health professional, is often applied as an efficient approach to making a nutrition-related diagnosis [15]. In high-risk settings, such as acute hip fracture units (with a high proportion of patients at malnutrition risk), the poor sensitivity of common screening tools and the need for prompt nutrition care, support proceeding straight to detailed assessment and intervention [15]. Nutrition screening to identify patients at risk of a nutrition deficiency, excess or imbalance state should be quick and easy and designed to be administered by diverse people with limited or no training [16].

\subsection{Interdisciplinary Assessment (S/MPLE)}

Where patients are identified at nutrition risk, appropriately trained interdisciplinary team members should undertake further nutrition assessment. The lack of distinction between screening and assessment measures, the diversity of nutrition-related diagnoses and factors contributing to their development and the presence of confounding co-morbid conditions have resulted in the absence of any gold standards for nutrition screening or diagnosis [17-19]. Not surprisingly, a range of nutrition screening and assessment tools have been applied or recommended in orthogeriatric settings; Table 18.1 applies an ABCDEF anagram to highlight nutrition assessment measures, screening tools and malnutrition diagnostic criteria commonly reported, observed, applied or recommended for use in orthogeriatric settings [4, 10, 15-38] (Table 18.1). Local treating teams should select measures, tools and diagnostic criteria that have proven concurrent and predictive validity in the population in which they are to be applied, and that are feasible for local implementation [19, 21, 39, 40].

The ease of retrospective access and cut-off measures have led to the continued practice of using single-point nutrition outcomes measures, such as BMI or albumin, in clinical and research settings $[17,22]$. Single measures may be appropriate for some specific nutrition-related diagnoses, for example some vitamin deficiency states. However, applying single measures for the definition of protein-energy malnutrition should probably be avoided. Protein-energy malnutrition has traditionally been assumed to apply to 'stick thin' patients with low BMIs. However, there is now a clear imperative to screen for malnutrition in overweight and obese as well as underweight older people [41]. Protein-energy malnutrition is evident across BMI ranges and the risks of increased morbidity and mortality associated with rapid loss of muscle mass are now becoming recognised across under-, overweight and obese BMI categories $[42,43]$. Serum albumin and other markers of visceral protein status are also not reliable as a standalone malnutrition markers in acutely unwell orthogeriatric populations $[18,44]$. Inflammation is today considered the major reason for 
Table 18.1 Nutrition assessment measures, screening tools and malnutrition diagnostic criteria commonly applied or recommended for use in orthogeriatric settings

\begin{tabular}{|c|c|}
\hline \multicolumn{2}{|l|}{ Nutrition assessment measures } \\
\hline \multicolumn{2}{|r|}{ D: Dietary intake assessment } \\
\hline composition & Food history \\
\hline Weight/weight changes & $24 \mathrm{~h}$ recall \\
\hline Height & Food records \\
\hline BMI & Diets and dietary restrictions e.g.: Special diet I Poor diet I \\
\hline Circumference measures & Monotonous diet \\
\hline Skinfold measures & E: Environmental and psycho-social assessment \\
\hline Bioelectrical impedance analysis & Social status, i.e. poverty, low education \\
\hline (BIA) & Living alone \\
\hline Dual-energy X-ray absorptiometry & Functional status \\
\hline (DXA) & Depression \\
\hline B: Biochemical measurement & Declined cognitive function \\
\hline Albumin & F: Functional measures \\
\hline Prealbumin & Walking test for distance or time \\
\hline Insulin-like growth factor-1 & Grip strength \\
\hline Retinol binding protein & Delayed cutaneous hypersensitivity \\
\hline Transferrin & Total lymphocyte count \\
\hline Glucose/HBA1C & Other: \\
\hline Liver function tests & Sarcopaenia consensus criteria \\
\hline Renal function tests & Frailty scores \\
\hline \multicolumn{2}{|l|}{ Electrolytes } \\
\hline \multicolumn{2}{|l|}{ C: Clinical history } \\
\hline \multicolumn{2}{|l|}{$\begin{array}{l}\text { Physiological contributors to } \\
\text { wasting }\end{array}$} \\
\hline \multicolumn{2}{|l|}{$\begin{array}{l}\text { Physiological contributors to } \\
\text { cachexia }\end{array}$} \\
\hline \multicolumn{2}{|l|}{$\begin{array}{l}\text { e.g. COPD, heart failure, some } \\
\text { cancers }\end{array}$} \\
\hline \multicolumn{2}{|c|}{ Screening tools for protein-energy malnutrition } \\
\hline Mini Nutrition Assessment [23] & Mini Nutrition Assessment- Short Form [27] \\
\hline Malnutrition screening tool [24] & Malnutrition Universal Screening Tool [10] \\
\hline Nutrition Risk Screening 2002 & Prognostic nutrition index [28] \\
\hline [25] & Simplified Nutrition Appetite Questionnaire [29] \\
\hline Index [26] & \\
\hline \multicolumn{2}{|c|}{ Criteria for protein-energy malnutrition diagnosis } \\
\hline ASPEN/Academy Criteria (2012) & GLIM criteria [33] \\
\hline [30] & ICD 10 criteria [34] \\
\hline ESPEN criteria (2015) [31] & Mini Nutrition Assessment- Short Form [27] \\
\hline \multicolumn{2}{|l|}{ Mini Nutrition Assessment [23] } \\
\hline Subjective Global Assessment & \\
\hline [32] & \\
\hline
\end{tabular}

reduced serum levels of visceral proteins, and inflammation due to disease or ageing is well recognised as a contributor to the development of malnutrition [44]. Inflammation is also a predictor of sepsis, longer hospital stay and readmission and mortality, so it is not surprising that studies report associations between low visceral proteins and poor patient and healthcare outcomes. 
Differences in study designs, populations, evidence-based outcomes, guidelines and consensus recommendations preclude making specific macro- or micronutrient recommendations. Consequently, local teams should consider latest evidence and relevant national or international recommendations for macro- and micronutrients. As a start point, ageing-related inefficiencies in absorption and utilisation suggest considering an energy intake target of $30 \mathrm{kcal} / \mathrm{kg}$ bodyweight daily in older patients, and at least $1 \mathrm{~g} / \mathrm{kg}$ protein with individual adjustment for nutritional status, physical activity level, disease status and tolerance $[45,46]$.

Dehydration should also be closely monitored as this can be causative for fracture incidence and a substantial and significant contributor to subsequent harm [47]. Unless a clinical comorbidity requires a different approach consensus daily recommendations suggest $1.6 \mathrm{~L}$ for women and $2.0 \mathrm{~L}$ for men with normal physical activity in a moderate climate $[46,48]$.

In summary, in many settings, a positive nutrition risk screen simply informs a referral for a thorough assessment and diagnosis by an appropriately trained nutrition care specialist, prior to commencing nutrition care interventions. A SIMPLE alternative is recommended; orthogeriatric teams need to action opportunities for systematised nutrition care from the point of risk identification. These may consider opportunities for timely nutrition diagnoses, goal setting, interventions and evaluation processes.

\subsection{Make the Diagnosis/(es) (SIMPLE)}

A broad array of nutrition-related diagnoses are observed across orthogeriatric settings and can result from deficiency, excess or imbalance states that lead to adverse effects on body form, function, clinical outcomes, healthcare systems and community costs (Table 18.2) [34].

Cachexia, sarcopaenia, frailty and osteoporosis are of particular interest, given their prevalence trajectories and likely impact on outcomes globally. Concurrent diagnoses, for example of obesity and malnutrition, are also worthy of special attention. The most outstanding single diagnosis in terms of reported prevalence, incidence and harm imposed on patient and healthcare systems is protein-energy malnutrition. In many settings globally, the skeleton continues to hide in the hospital closet; undervalued, under-recognised, and consequently, undertreated [49, 50].

Protein-energy malnutrition (malnutrition) is an ICD-coded condition that can be treated using medical nutrition therapy [34]. Its prevalence varies across orthogeriatric settings, reflecting differences in screening and diagnostic tools, as well as real differences in the populations observed. Estimates suggest that less than 1 in 3 non-complex elective orthogeriatric inpatients are at risk of malnutrition, whilst up to two-thirds of hip fracture patients will have a diagnosis of protein-energy malnutrition by the time they are discharged from acute or rehabilitation care settings [36, 50]. Although differences in design and tools again make comparisons difficult, the reported prevalence appears higher in studies from low- and middle-income counties than in high-income countries [51,52]. 
Table 18.2 Common nutrition-related diagnoses observed or reported within and across global orthogeriatric settings-with ICD-10 Diagnostic Code [34]

\section{Undernutrition}

- Protein-energy malnutrition-serve E43/moderate E44/unspecified E46

- Starvation related underweight-E43

- Anorexia of ageing-R63.0

- Wasting-M62.5

- Cachexia/disease-related malnutrition-R64

- Nutritional marasmus-E41

- Sarcopenia-M62.84

- Frailty-R54

- Dehydration-E86.0

Micronutrient deficiency -E56.9

- Vitamin D deficiency-E55

- Vitamin B12 deficiency-E53.8/intrinsic factor deficiency D51.0

- Iron deficiency-E61.1/anaemia D50

Overnutrition

- Overweight-E66.3

- Obesity-E66.9

- Fatty liver disease/non-alcoholic steatohepatitis-K76.0

- Excessive alcohol intake-F10.99

Nutrition imbalance states/metabolic disorders/autoimmune

- Osteopenia-M85.80

- Osteoporosis-M81.0/with fracture M80.0

- Diabetes mellitus-DM1 E10/DM2 E11

- Acute kidney injury-Unspecified N17.9

- Chronic kidney disease-Unspecified N18.9

- Irritable bowel syndrome-K58

- Refeeding syndrome-Endocrine, nutritional and metabolic disease E00-E89/disorder of electrolyte and fluid balance E87. 8

Protein-energy malnutrition is recognised as the most costly comorbidity in hip fracture, the one most likely to increase length of stay and a strong independent predictor of post discharge mortality [53, 54]. Table 18.3 highlights associations between protein-energy malnutrition and outcomes observed across orthopaedic specified studies and those including older, multimorbid populations including those with fragility fractures [18, 54-63].

Recent updates to key orthogeriatric evidence-based recommendations, guidelines and registry datasets suggest positive, albeit belated, recognition of the need for timely identification, treatment and monitoring of nutrition care across the acute, rehabilitation and secondary prevention orthogeriatric settings globally.

A thorough assessment will also identify the aetiology, or root cause, of the nutrition-related diagnosis or diagnoses being assessed [9]. A comprehensive list of all potential aetiologies observed in orthogeriatric settings is beyond the remit of this chapter, however, Table 18.4 provides some potential starting points for consideration $[17,37,50]$.

Efforts to identify a primary aetiology for a nutrition-related diagnosis in older, multimorbid inpatients are difficult, and perhaps over-simplistic [64]. For example, protein-energy malnutrition may be attributable to wasting, cachexia or a combination 
Table 18.3 Association between protein-energy malnutrition and outcomes in orthogeriatric settings

\begin{tabular}{|c|c|}
\hline Affected & Outcome \\
\hline Patient & $\begin{array}{l}\text { Altered body composition /sarcopaenia } \\
\text { Reduced mobility/frailty/falls } \\
\text { Post-operative complications } \\
\quad \text { Increased infection risk } \\
\text { Pressure injuries } \\
\text { Wound complications } \\
\text { Functional impairment/apaty } \\
\text { Psychological effects/tendency to depression, anxiety, impaired social } \\
\text { function } \\
\text { Delirium } \\
\text { Reduced quality of life } \\
\text { Unfavourable discharge destination } \\
\text { Life expectancy }\end{array}$ \\
\hline $\begin{array}{l}\text { Healthcare } \\
\text { system }\end{array}$ & $\begin{array}{l}\text { Increased hospital-acquired complications } \\
\text { Infections/wound dehiscence } \\
\text { Pressure injuries } \\
\text { Harmful falls } \\
\text { Delirium } \\
\text { Increased length of stay } \\
\text { Increased healthcare costs } \\
\text { Unfavourable discharge } \\
\text { Unplanned hospital readmissions } \\
\text { Increased requirements for rehabilitation } \\
\text { Increased requirements for long term care }\end{array}$ \\
\hline Society & $\begin{array}{l}\text { Increased caregiver burden } \\
\text { Increased societal healthcare costs }\end{array}$ \\
\hline
\end{tabular}

of these [30]. This is further confounded by the complex relationships and substantial overlap in variables applied for the purposes of screening and diagnosing proteinenergy malnutrition, wasting, cachexia, sarcopaenia, frailty, osteoporosis and other nutrition-related diagnoses [65]. It is therefore unsurprising that malnutrition is considered a 'wicked' problem [66, 67] (Table 18.5). A pragmatic approach would consider whether administration of nutritional intervention is likely to improve outcomes; if so then the aetiology is likely to include a nutritional component and locally tailored nutrition interventions should be provided.

Once diagnoses and aetiologies have been articulated, these should be documented in the appropriate care record. Proper documentation is critical to providing quality standard care, communication with other professions and recording diagnosis that can have effects on other medical diagnosis or treatment [68]. Documentation also supports service planning and review processes, and in many settings also influences resource allocation.

Multidisciplinary clinicians should ensure that patients are aware of positive nutrition risk screens. Open and honest discussion about consequent nutritionrelated diagnoses and a shared decision-making approach to treatment (and no treatment) options should be considered within a sensitive approach that allows patients or carers to control the amount of information they receive [46, 69]. 
Table 18.4 Commonly observed determinants of nutrition-related diagnoses across orthogeriatric settings

\begin{tabular}{|c|c|}
\hline $\begin{array}{l}\text { Physiological } \\
\text { Age } \\
\text { Cognitive impairment, dementia, or delirium } \\
\text { Depression } \\
\text { Dysphagia/swallowing difficulties/chewing difficulties/ } \\
\text { Edentulism } \\
\text { Dysgeusia/taste changes } \\
\text { Eating dependencies - } \\
\text { Frailty, functional and/or physical decline } \\
\text { Lifestyle diseases } \\
\text { Medical co-morbidities - } \\
\text { Pain } \\
\text { Polypharmacy/medication side effects } \\
\text { Poor appetite/anorexia of old age } \\
\text { Poor or moderate self-reported health status } \\
\text { Sarcopaenia } \\
\text { Small or large bowel dysfunction } \\
\text { Xerostomia/dry mouth } \\
\text { Psychosocial } \\
\text { Carer burden } \\
\text { Financial hardship } \\
\text { Loss of interest in life/emotional well being } \\
\text { Social isolation } \\
\text { Food habits and preferences } \\
\text { Societal norms, trends and peer pressure }\end{array}$ & $\begin{array}{l}\text { Workplace cultural } \\
\text { Competing interests/priorities } \\
\text { Cost 'saving' false economies } \\
\text { Deferral of accountability } \\
\text { Role accountabilities, } \\
\text { requirements and redefinitions } \\
\text { Task minimisation } \\
\text { Environmental } \\
\text { Institutional environments and } \\
\text { processes } \\
\text { Food and fluid access } \\
\text { Transportation (dependent on) } \\
\text { Clinician capability and capacity } \\
\text { Perceptions, misinformation, and } \\
\text { biases } \\
\text { Nutrition knowledge and } \\
\text { misinformation } \\
\text { Restrictive diets } \\
\text { Patient, clinician and community } \\
\text { perceptions } \\
\text { Normalisation } \\
\text { Phobias } \\
\text { Unjustified resistance } \\
\text { Treatment bias }\end{array}$ \\
\hline
\end{tabular}

Table 18.5 Why malnutrition should be considered a wicked problem

- No gold standard screen or diagnosis

- Multiple aetiologies

- No single, clear intervention

- Socially complex

- Not the responsibility of single stakeholder/professional group

- Characterised by chronic policy failure

- Solutions require behaviour change

A 'truth-telling' approach to informing patients of a diagnosis of malnutrition, for example may initially appear confronting. However, studies suggest that patients' wish to understand a harmful diagnosis such as malnutrition far outweighs concerns over potential disbenefits of receiving this advice [69]. Recognition of a problem is a primary first step towards positive change, and awareness of nutrition status may positively influence treatment adherence or patient experiences.

\subsection{Plan with the Patient (SIMPLE)}

Wicked problems do not have magic bullets for care [70]. Multi-modal, interdisciplinary interventions should be considered to treat nutrition diagnoses, aetiologies or related conditions at both the individual and systems levels [9, 31, 38, 46, 71, 72]. 
Nutrition interventions planned at the individual level should consider a shared decision-making approach, including informed consent. This should be applied to establish nutrition treatment goals and intervention strategies and to establish monitoring and reassessment processes to identify whether interventions are effective and consistent with patient goals and healthcare system deliverables $[3,9,46,73$, 74]. Whilst these care processes are presented in linear fashion, this is not how care will or should be delivered in many real-world settings. Orthogeriatric teams should also engage patients in co-design approaches to improve systems, processes, resources, environmental and governance structures that facilitate delivery of nutrition care across the three pillars of care $[1,75,76]$.

To the best of our knowledge, no specific literature has focused its attention on the need for shared decision-making or co-design in orthogeriatics. Nevertheless, increasing evidence suggests the importance of these components in the nutritional care of frail and older patients. Patients should be encouraged to become more active in goal setting and developing strategies for ongoing care; these should ideally be patient-driven and support patients and/or carers to make 'informed choices' about treatment options [77]. This is especially important in the absence of a 'one strategy fits all' approach to nutrition care. Building behaviour change through setting small realistic goals, encouraging self-monitoring, providing positive feedback and health coaching are also potential opportunities that could implemented by interdisciplinary healthcare workers across orthopaedic settings [77]. Perhaps most importantly, goals and strategies should be individualised to consider the patients' stage of change, health literacy, cognition and cultural needs [77]. Involving family and other significant support people, particularly those who are primary meal providers, in nutrition education strategies may positively influence behaviour change [77].

Who is best placed to facilitate appropriate goal-setting with patients varies across settings; how, when and where this takes occurs is also highly contextual. As an example, in a palliative situation, the patient should be offered whatever he or she likes to eat and drink orally, in the amount he or she likes to consume, regardless of nutrition status. This approach is mostly described by the term comfort feeding [78]. In this situation, meeting a patient's nutritional requirements is obviously irrelevant, and nutrition treatment goals and strategies should focus on their comfort [79]. In contrast, the appropriateness of reinserting an enteral feeding tube, after its removal by a malnourished, acutely delirious hip fracture patient, is far more complex and would require attention to clinical judgement and shared decision-making [80, 81].

\subsection{ImpLement Interventions (SIMPLE)}

\subsubsection{Interventions to Improve Nutrition Knowledge}

The ESPEN guideline on clinical nutrition in geriatrics consequently recommends that patients and caregivers should be offered nutritional education in order to ensure awareness of, and basic knowledge on, nutritional problems and treatment options, to promote their appropriate nutrition care [46]. 
Effective education of patients and healthcare workers should not just provide patients with basic information about nutrient sources and place posters in hospital ward treatment areas. As a first step in any patient education or counselling process, the information provider should ensure the patient is aware or the relevant nutrition diagnosis or diagnoses. The lack of recognition of the need to change is considered the fundamental barrier to commencement of change [82, 83].

A multicentre nutritional intervention study suggested additional factors that can enhance adherence in older patients after hip fracture [84]. Individualised dietary advice, frequent personal coaching by the health professional and continuity of care (monitoring, personnel and type of advice) are likely to contribute to greater adherence. Moreover, they seem to elicit high appreciation of the intervention by both participant and caregivers. A further study demonstrated that nutrition care is not a priority of hip fracture patients and their healthcare providers because people fail to pay enough attention to patient and healthcare worker perceptions, biases and beliefs [50].

Strategies to improve nutrition knowledge and awareness should also not be limited to patients, carers and direct healthcare providers. Health education theory, research and training processes should be used to modify social and political environments to improve health [85]. Where available, 'outer setting' nutrition care drivers should be considered. Examples include care standards, accreditation requirements, hospital-acquired complication penalties, case-based reimbursement funding and benchmarked audit data sets. These should be leveraged to promote orthogeriatric nutrition care to healthcare executives, politicians, media, insurance and research-funding bodies [86]. Where such drivers are absent, orthogeriatric teams should advocate for their development and implementation.

\subsubsection{Interventions to Influence Nutrient Intake}

Numerous studies demonstrate that patients with hip fracture, and older adults in the acute and rehabilitation settings more generally, commonly fail to meet rudimentary recommendations for macronutrient, micronutrient and fluid intakes. In many cases, multiple nutrition-related diagnoses co-exist, for example in malnourished patients with co-diagnoses of obesity and pressure injuries; in such cases, clinical care processes are best supported by dietitians or medical nutrition specialists, where available [42].

In most cases, the underlying treatment strategies for patients with undernutrition revolve around the deficient nutrient or nutrients, whether protein and/or energy, fluids or micronutrients. Ensuring adequate provision and intake of fluids and micronutrients may not be an insurmountable challenge in acute, rehabilitation and secondary prevention settings with appropriate application of intravenous therapy and pharmaceutical support. Nonetheless, dehydration is still commonly observed, vitamin $\mathrm{D}$ and other micronutrient deficiencies often remain untreated and a high proportion of post-fracture patients fail to receive adequate bone protection medication. However, the most difficult challenge is the increased protein requirements of acutely unwell, older, multimorbid patients. Many intervention studies demonstrate persistent inadequate intakes with concomitant harm, even after intervention. 
There is no single intervention that will guarantee delivery of protein and energy intake adequacy across acute, rehabilitation, community or residential care home settings. Multimodal approaches that engage patients and treating teams in the identification of locally relevant, multimodal strategies seem more likely to yield improved intakes, patient and healthcare outcomes and patient-reported experiences.

Table 18.6 lists systematised and/or interdisciplinary strategies that are considered to positively influence macronutrient, micronutrient and/or fluid intake across orthogeriatric settings $[6,9,17,22,38,46,71,72,89]$. Specific strategies for nutrition care should be considered by local teams after considering relevant evidence-based recommendations and tailoring interventions to the local context and patient needs.

Table 18.6 Systematised and/or interdisciplinary strategies to influence food and nutrition intake

\begin{tabular}{|c|c|c|}
\hline $\begin{array}{l}\text { Food, fluid } \\
\text { and nutrient } \\
\text { access }\end{array}$ & $\begin{array}{l}\text { - Assistance with access, preparation } \\
\text { or storage } \\
\text { - Assistive devices e.g. modified } \\
\text { cutlery } \\
\text { - Access to macro- and micronutrient } \\
\text { supplements } \\
\text { - Allocation of funding and resources } \\
\text { - Avoidance of prolonged Nil By } \\
\text { Mouth, unnecessary post-surgical } \\
\text { diets and/or restrictive diets } \\
\text { - Clinical nutrition governance } \\
\text { processes } \\
\text { - Enjoyable eating experiences and } \\
\text { mealtime settings } \\
\text { - Family/friends support } \\
\text { - Food or fluid enrichment or } \\
\text { functional changes } \\
\text { - Food supply influence high-quality } \\
\text { food and fluid choices/menus } \\
\text { - Mealtime preparedness activities }\end{array}$ & $\begin{array}{l}\text { - Menu standards, policies and } \\
\text { procedures } \\
\text { - Modified menus e.g. high protein; } \\
\text { texture-modified menu assistance and } \\
\text { dietary preference checks } \\
\text { - Multidisciplinary assistance and } \\
\text { encouragement with food, fluid or } \\
\text { supplement intake } \\
\text { - Nutrition support teams } \\
\text { - Provision for inclusion of nutrition } \\
\text { supplements on medication } \\
\text { administration records } \\
\text { - Strategies to improve mobility/ } \\
\text { functional status } \\
\text { - Supportive nutrition care } \\
\text { coordination roles (e.g. nutrition } \\
\text { assistants) } \\
\text { - Systems supporting interdisciplinary } \\
\text { ordering/administration/assistance } \\
\text { - Volunteer assistance }\end{array}$ \\
\hline $\begin{array}{l}\text { Prescription } \\
\text { and } \\
\text { deprescription }\end{array}$ & $\begin{array}{l}\text { Prescription } \\
\text { - Activities, therapies, or medications } \\
\text { to: } \\
\text { - Optimise underlying conditions } \\
\text { or comorbidities } \\
\text { - Manage nutrition impact } \\
\text { symptoms } \\
\text { - Influence appetite or intake } \\
\text { - Improve mental health and } \\
\text { wellbeing } \\
\text { - High protein-energy oral nutrition } \\
\text { supplements (e.g. Fluids, protein } \\
\text { powders) } \\
\text { - Individual or multi-nutrient } \\
\text { micronutrient supplements } \\
\text { - IV fluid therapy, enteral, or } \\
\text { parenteral nutrition where } \\
\text { appropriate and in line with patient } \\
\text { goals/healthcare plans }\end{array}$ & $\begin{array}{l}\text { Deprescription } \\
\text { - Medication deprescription or dose } \\
\text { adjustment } \\
\text { - Mixed approaches } \\
\text { (dietary } \pm \text { supplements } \pm \text { enteral or } \\
\text { parenteral tube feeding) } \\
\text { - Nutrition therapy where treatment } \\
\text { goals or requirements no longer } \\
\text { support medical nutrition therapy } \\
\text { - Restrictive diets were unlikely to add } \\
\text { benefit/negatively influencing } \\
\text { nutrition status }\end{array}$ \\
\hline
\end{tabular}


Table 18.6 (continued)

\begin{tabular}{|c|c|c|}
\hline Education & $\begin{array}{l}\text { - Dietary counselling } \\
\text { - Inclusion of nutrition curriculum in } \\
\text { interdisciplinary training and } \\
\text { education } \\
\text { - Informed consent discussions } \\
\text { - Mobile Health (mHealth) } \\
\text { applications nutrition component in } \\
\text { ward rounds, huddles, case } \\
\text { conferences, interdisciplinary care } \\
\text { planning meetings }\end{array}$ & $\begin{array}{l}\text { - Nutrition-related diagnosis and } \\
\text { education provided to patients, } \\
\text { caregivers and health professionals } \\
\text { - Nutrition specialist representation in } \\
\text { advocacy and governance roles } \\
\text { - Quality improvement, research and } \\
\text { development shared goal setting and } \\
\text { treatment planning } \\
\text { - Standards, policies, guidelines } \\
\text { - Traditional and social media } \\
\text { marketing }\end{array}$ \\
\hline Psychosocial & $\begin{array}{l}\text { - Group interventions } \\
\text { - Shared mealtimes/dining rooms } \\
\text { - Social support networks }\end{array}$ & $\begin{array}{l}\text { - Wellness/lifestyle/mindfulness/ } \\
\text { cognitive behaviour therapy programs }\end{array}$ \\
\hline Monitoring & $\begin{array}{l}\text { - Audits (nutrition care included in } \\
\text { orthogeriatric audits; nutrition- } \\
\text { specific audits/sprints) } \\
\text { Anthropometric monitoring } \\
\text { - Biochemistry/pathology/vitamin/ } \\
\text { mineral assays } \\
\text { - Food intake monitoring } \\
\text { - Nutrition re-screening }\end{array}$ & $\begin{array}{l}\text { - Nutrition re-assessments } \\
\text { - Patient-reported experience and } \\
\text { outcomes measures (PROMS/ } \\
\text { PREMS) } \\
\text { - Physical and functional re-assessment }\end{array}$ \\
\hline $\begin{array}{l}\text { Clinical } \\
\text { handover/care } \\
\text { across the } \\
\text { continuum }\end{array}$ & $\begin{array}{l}\text { - Discharge summaries/clinical } \\
\text { handover documents } \\
\text { - mHealth apps } \\
\text { - Nutrition specific fields in eHealth } \\
\text { records and systems }\end{array}$ & $\begin{array}{l}\text { - Referrals for ongoing care } \\
\text { - Self-management processes }\end{array}$ \\
\hline
\end{tabular}

\subsubsection{Interventions Leading to Coordinated Nutrition Care Across Disciplines and Settings}

It is well recognised that dietitians, nutritionists and medical nutrition specialists are experts in nutrition care. However, in many settings, access to nutrition care experts is limited outside of acute care facilities or tertiary rehabilitation settings. In some healthcare settings, dietitians and medical nutrition specialists may be best placed to coordinate nutrition care across disciplines and settings, but this may not always be an option. Appropriately educated patients and their family, friends and social networks are also often ideally placed to provide supportive nutrition care.

Of focus though are the many interdisciplinary healthcare workers that orthogeriatric patients interface with across the three pillars of orthogeriatric care who may be able to provide supportive nutrition care processes. Where available, dietetic (or nutrition) assistants are particularly well best placed; but dietetic assistants are also not available in many settings even though they have been shown to reduce mortality in hip fracture [87].

As described in Chap. 17, the best-placed profession to oversee, lead and implement interventions to coordinate nutrition care is therefore nursing. Nurses are usually the main professional group providing care to patients and the best-placed 
professional group to coordinate systematised or interdisciplinary nutrition care processes where specialist care is not available or is unlikely to add benefit. Nurses also have the most significant amounts of repeat-contact with patients and carers in different settings, whether over the full 24 -h period in acute and rehabilitation settings, or in other situations such as secondary prevention settings and home care.

Nurses also witness patients' eating and drinking activities, have a strong understanding of barriers and enablers to nutrition intake, and are likely to be best placed to understand where the patient 'fits' within a social-ecological setting. This makes them ideal coordinators and champions of nutritional aspects of care. Nurses are often in the best position to conduct primary nutritional screening and assessment that identifies those in need of nutritional support to be provided solely by nurses or in collaboration with other members of the orthogeriatric team, or specialist care where accessible and likely to add benefit. In settings where dietitian, nutritionist or medical nutrition specialist resources are limited, nurses can provide excellent nutritional care to most patients whilst allowing nutrition specialists to focus on the most in need of their expertise.

Most, if not all of the strategies listed in Table 18.6 are considered to sit squarely in remit of nursing-led essential care [88]. Although it is difficult to identify an evidence base for such fundamental aspects of nursing care, such nurse-led interventions are likely to have a positive impact on nutritional status [89]. These fundamental aspects of nursing care are the responsibility of the whole nursing team, but require co-ordination and leadership so that they are a priority. In many settings, nursing professionals are well placed to guide allocation of resources, alterations to institutional structures and organisational process reform.

A call to action is therefore made to global and local nursing leadership to engage patients, interdisciplinary teams and broad stakeholders to deliver high-value nutrition care across the three pillars of orthogeriatrics.

\subsection{Evaluating Ongoing Care Requirements (SIMPLE)}

Patients with or at risk of a nutrition-related diagnosis will routinely require nutrition monitoring or re-assessment strategies. Processes for re-screening should also be considered for those not currently at risk. What needs to be monitored, how often, and by whom will depend on many factors, perhaps most notably the nutrition diagnosis in question, and resource constraints. This makes it challenging to provide definitive recommendations for clinical handover across the care pathway.

Local treating teams need to work with patients to identify the best opportunities for ongoing nutritional monitoring and evaluation. Discussions may consider the availability of access to specialist nutrition outpatient or community services and the potential benefits, costs and opportunity costs of these. Other alternatives for consideration could include general practitioners, nurse practitioners, mHealth programs, group programs or self-monitoring.

Finally, clinical audits of care delivery positively influence patient and healthcare outcomes. Table 18.7 provides a summative recap of potential opportunities for 
Table 18.7 Evaluating nutritional care of the older patient with fragility fracture

\begin{tabular}{|c|c|c|}
\hline & Nutrition care opportunity & Audit opportunity \\
\hline $\mathbf{S}$ & Screen for nutrition risk & $\begin{array}{l}\text { Proportion of patients screened using a valid nutrition } \\
\text { screening tool }\end{array}$ \\
\hline I & Interdisciplinary assessment & $\begin{array}{l}\text { On admission nutrition assessment completed } \\
\text { Weight documented within } 72 \mathrm{~h} \text { of admission }\end{array}$ \\
\hline M & Make diagnosis (es) & $\begin{array}{l}\text { Proportion of patients with a documented nutrition } \\
\text { diagnosis using a tool with adequate concurrent and } \\
\text { predictive validity }\end{array}$ \\
\hline $\mathbf{P}$ & $\begin{array}{l}\text { Plan with the patient-Goal } \\
\text { setting and informed consent }\end{array}$ & $\begin{array}{l}\text { Documented or patient-reported informed consent } \\
\text { discussion regarding diagnosis and treatment plan }\end{array}$ \\
\hline $\mathbf{L}$ & $\begin{array}{l}\text { impLement interventions using } \\
\text { systems and teams }\end{array}$ & $\begin{array}{l}\text { Documented or patient-reported provision of: } \\
\text { Nutrition education } \\
\text { Food intake strategy(ies) } \\
\text { Nutrition care plan }\end{array}$ \\
\hline $\mathbf{E}$ & Evaluate ongoing care options & Nutrition audit report \\
\hline
\end{tabular}

systematised, interdisciplinary nutrition care approaches across acute care, rehabilitation and secondary prevention orthogeriatric settings, and how these may be evaluated [3].

\subsection{Recommended Further Reading}

- Bell JJ et al (2018) Rationale and developmental methodology for the SIMPLE approach: a Systematised, Interdisciplinary Malnutrition Pathway for impLementation and Evaluation in hospitals. Nutr Diet 75(2):226-234

- King PC et al (2019) "I wouldn't ever want it": a qualitative evaluation of patient and caregiver perceptions toward enteral tube feeding in hip fracture inpatients. J Parenter Enteral Nutr 43(4):526-533

- Volkert D et al (2019) ESPEN guideline on clinical nutrition and hydration in geriatrics. Clin Nutr 38(1):10-47

\section{References}

1. Dreinhöfer KE et al (2018) A global call to action to improve the care of people with fragility fractures. Injury 49(8):1393-1397

2. Pioli G, Giusti A, Barone A (2008) Orthogeriatric care for the elderly with hip fractures: where are we? Aging-Clin Exp Res 20(2):113-122

3. Bell JJ et al (2018) Rationale and developmental methodology for the SIMPLE approach: a Systematised, Interdisciplinary Malnutrition Pathway for impLementation and Evaluation in hospitals. Nutr Diet 75(2):226-234

4. Jensen GL et al (2013) Recognizing malnutrition in adults: definitions and characteristics, screening, assessment, and team approach. J Parenter Enter Nutr 37(6):802-807

5. Keller Het al (2018) Update on the Integrated Nutrition Pathway for Acute Care (INPAC): post implementation tailoring and toolkit to support practice improvements. Nutr J 17(1):2

6. Bell JJ et al (2014) Multidisciplinary, multi-modal nutritional care in acute hip fracture inpatients—results of a pragmatic intervention. Clin Nutr 33(6):1101-1107 
7. Bell JJ et al (2014) Developing and evaluating interventions that are applicable and relevant to inpatients and those who care for them; a multiphase, pragmatic action research approach. BMC Med Res Methodol 14:98

8. Graham ID et al (2006) Lost in knowledge translation: time for a map? J Contin Educ Heal Prof 26(1):13-24

9. Writing Group of the Nutrition Care Process/Standardized Language Committee (2008) Nutrition care process and model part I: the 2008 update. J Am Diet Assoc 108(7):1113-1117

10. Elia M (2003) Screening for malnutrition: a multidisciplinary responsibility. Development and Use of the Malnutrition Universal Screening Tool (MUST) for Adults, ed. B.A.f.P.a.E. Nutrition. BAPEN, Redditch

11. Laur C et al (2017) Changing nutrition care practices in hospital: a thematic analysis of hospital staff perspectives. BMC Health Serv Res 17(1):498

12. Queensland Clinical Senate (2016) Value-based healthcare-shifting from volume to value. 2016 [cited 2017 September 27]. https://www.health.qld.gov.au/_data/assets/pdf_ file/0028/442693/qcs-meeting-report-201603.pdf

13. Palmer S, Raftery J (1999) Opportunity cost. BMJ 318(7197):1551

14. Laur C et al (2018) The Sustain and Spread Framework: strategies for sustaining and spreading nutrition care improvements in acute care based on thematic analysis from the More-2-Eat study (Report). BMC Health Serv Res 18(1):930

15. Bell JJ et al (2014) Quick and easy is not without cost: implications of poorly performing nutrition screening tools in hip fracture. J Am Geriatr Soc 62(2):237-243

16. Bell $\mathrm{J}$ et al (2014) Mobilising nutrition diagnoses beyond protein-energy malnutrition in patients with acute hip fracture. Nutr Diet 71(S1):35

17. Bell JJ (2014) Identifying and overcoming barriers to nutrition care in acute hip fracture inpatients, PhD thesis. School of Human Movement and Nutrition Sciences. The University of Queensland

18. Bell JJ et al (2014) Concurrent and predictive evaluation of malnutrition diagnostic measures in hip fracture inpatients: a diagnostic accuracy study. Eur J Clin Nutr 68(3):358-362

19. Elia M, Stratton RJ (2011) Considerations for screening tool selection and role of predictive and concurrent validity. Curr Opin Clin Nutr Metab Care 14(5):425-433

20. Bell JJ et al (2013) Quick and easy in theory but costly in practice? Implications of poorly performing nutrition screening tools in hip fracture. Clin Nutr 32(Suppl 1):s76

21. Marshall WJ (2008) Nutritional assessment: its role in the provision of nutritional support. J Clin Pathol 61(10):1083-1088

22. Bell JJ (2018) Nutrition support in orthopaedics. In: Hickson M, Smith S, editors. Advanced nutrition and dietetics in nutrition support. John Wiley and Sons, Oxford

23. Guigoz Y, Vellas B (1999) The mini nutritional assessment (MNA) for grading the nutritional state of elderly patients: presentation of the MNA, history and validation. Nestle Nutr Workshop Ser Clin Perform Programme 1:3-11; discussion 11-12

24. Ferguson M et al (1999) Development of a valid and reliable malnutrition screening tool for adult acute hospital patients. Nutrition 15(6):458-464

25. Kondrup J et al (2003) Nutritional risk screening (NRS 2002): a new method based on an analysis of controlled clinical trials. Clin Nutr 22(3):321-336

26. Rainey-Macdonald CG et al (1983) Validity of a two-variable nutritional index for use in selecting candidates for nutritional support. J Parenter Enter Nutr 7(1):15-20

27. Kaiser MJ et al (2009) Validation of the Mini Nutritional Assessment short-form (MNA-SF): a practical tool for identification of nutritional status. J Nutr Health Aging 13(9):782-788

28. Buzby GP et al (1980) Prognostic nutritional index in gastrointestinal surgery. Am J Surg 139(1):160-167

29. Kruizenga HM et al (2005) Development and validation of a hospital screening tool for malnutrition: the short nutritional assessment questionnaire (SNAQ). Clin Nutr 24(1):75-82

30. White JV et al (2012) Consensus statement: Academy of Nutrition and Dietetics and American Society for Parenteral and Enteral Nutrition: characteristics recommended for the 
identification and documentation of adult malnutrition (undernutrition). J Parenter Enteral Nutr 36(3):275-283

31. Cederholm $\mathrm{T}$ et al (2015) Diagnostic criteria for malnutrition-an ESPEN Consensus Statement. Clin Nutr 34(3):335-340

32. Detsky AS et al (1987) What is subjective global assessment of nutritional status? J Parenter Enteral Nutr 11(1):8-13

33. Cederholm T et al (2019) GLIM criteria for the diagnosis of malnutrition - a consensus report from the global clinical nutrition community. Clin Nutr 38(1):1-9

34. World Health Organisation (2010) International Statistical Classification of Diseases and Related Health Problems 10th Revision. https://icd.who.int/browse10/2016/en

35. Stratton RJ, Green CJ, Elia M (2003) Disease-related malnutrition: an evidence-based approach to treatment. CABI Publishing, Wallingford

36. Barker LA, Gout BS, Crowe TC (2011) Hospital malnutrition: prevalence, identification and impact on patients and the healthcare system. Int J Environ Res Public Health 8(2):514-527

37. Bell J (2018) Nutrition screening and assessment in hip fracture. In: Preedy V, Patel VB, editors. Handbook of famine, starvation, and nutrient deprivation: from biology to policy. Springer International Publishing, Cham, pp 1-22

38. NICE (2012) NICE Quality Standard 24: Quality Standard for Nutrition Support in Adults. NICE: UK

39. Bowen DJ et al (2009) How we design feasibility studies. Am J Prev Med 36(5):452-457

40. Proctor E et al (2011) Outcomes for implementation research: conceptual distinctions, measurement challenges, and research agenda. Admin Pol Ment Health 38(2):65-76

41. Ng WL et al (2019) Evaluating the concurrent validity of body mass index (BMI) in the identification of malnutrition in older hospital inpatients. Clin Nutr 38(5):2417-2422

42. Ness SJ et al (2018) The pressures of obesity: the relationship between obesity, malnutrition and pressure injuries in hospital inpatients. Clin Nutr 37(5):1569-1574

43. Soeters PB, Schols AMWJ (2009) Advances in understanding and assessing malnutrition. Curr Opin Clin Nutr Metab Care 12(5):487-494

44. Soeters PB, Wolfe RR, Shenkin A (2019) Hypoalbuminemia: pathogenesis and clinical significance. JPEN J Parenter Enteral Nutr 43(2):181-193

45. Alix E et al (2007) Energy requirements in hospitalized elderly people. J Am Geriatr Soc 55(7):1085-1089

46. Volkert D et al (2019) ESPEN guideline on clinical nutrition and hydration in geriatrics. Clin Nutr 38(1):10-47

47. Renneboog B et al (2006) Mild chronic hyponatremia is associated with falls, unsteadiness, and attention deficits. Am J Med 119(1):71.e1-71.e8

48. EFSA Panel on Dietetic Products, Nutrition and Allergies (2010) Scientific opinion on dietary reference values for water. EFSA J 8(3):1459

49. Butterworth CE (1994) The skeleton in the hospital closet. Nutrition 10(5):435-441; discussion 435,441

50. Bell JJ et al (2013) Barriers to nutritional intake in patients with acute hip fracture: time to treat malnutrition as a disease and food as a medicine? Can J Physiol Pharmacol 91(6):489-495

51. Margetts BM et al (2003) Prevalence of risk of undernutrition is associated with poor health status in older people in the UK. Eur J Clin Nutr 57(1):69-74

52. Kabir ZN et al (2006) Mini Nutritional Assessment of rural elderly people in Bangladesh: the impact of demographic, socio-economic and health factors. Public Health Nutr 9(8):968-974

53. Nikkel LE et al (2012) Impact of comorbidities on hospitalization costs following hip fracture. J Bone Joint Surg Am 94(1):9-17

54. Bell JJ et al (2016) Impact of malnutrition on 12-month mortality following acute hip fracture. ANZ J Surg 86(3):157-161

55. Diekmann R, Wojzischke J (2018) The role of nutrition in geriatric rehabilitation. Curr Opin Clin Nutr Metab Care 21(1):14-18

56. Tana $\mathrm{C}$ et al (2019) Impact of nutritional status on caregiver burden of elderly outpatients. A cross-sectional study. Nutrients 11(2):281 
57. Goisser $\mathrm{S}$ et al (2015) Malnutrition according to mini nutritional assessment is associated with severe functional impairment in geriatric patients before and up to 6 months after hip fracture. J Am Med Dir Assoc 16(8):661-667

58. Malafarina $\mathrm{V}$ et al (2018) Nutritional status and nutritional treatment are related to outcomes and mortality in older adults with hip f555racture. Nutrients 10(5)

59. Mazzola P et al (2017) Association between preoperative malnutrition and postoperative delirium after hip fracture surgery in older adults. J Am Geriatr Soc 65(6):1222-1228

60. Freijer $\mathrm{K}$ et al (2013) The economic costs of disease related malnutrition. Clin Nutr 32(1):136-141

61. Curtis LJ et al (2017) Costs of hospital malnutrition. Clin Nutr 36(5):1391-1396

62. Sharma Y et al (2018) Economic evaluation of an extended nutritional intervention in older Australian hospitalized patients: a randomized controlled trial. BMC Geriatr 18(1):41-41

63. Elia M (2015) The cost of malnutrition in England and potential cost savings from nutritional interventions (short version): A report on the cost of disease-related malnutrition in England and a budget impact analysis of implementing the NICE clinical guidelines/quality standard on nutritional support in adults. NHS

64. Writing Group of the Nutrition Care Process/Standardized Language Committee (2008) Nutrition care process part II: using the International Dietetics and Nutrition Terminology to document the nutrition care process. J Am Diet Assoc 108(8):1287-1293

65. Cederholm T et al (2017) ESPEN guidelines on definitions and terminology of clinical nutrition. Clin Nutr 36(1):49-64

66. Rittel HWJ, Webber MM (1973) Dilemmas in a general theory of planning. Policy Sci 4(2):155-169

67. Young AM (2015) Solving the wicked problem of hospital malnutrition. Nutr Diet 72(3):200-204

68. Mathioudakis A et al (2016) How to keep good clinical records. Breathe (Sheffield, England) 12(4):369-373

69. Scott D et al (2016) Health care professionals' experience, understanding and perception of need of advanced cancer patients with cachexia and their families: the benefits of a dedicated clinic. BMC Palliat Care 15(1):100

70. Strebhardt K, Ullrich A (2008) Paul Ehrlich's magic bullet concept: 100 years of progress. Nat Rev Cancer 8(6):473-480

71. Watterson C, Fraser A, Banks M (2009) Evidence based practise guidelines for the nutritional management of malnutrition in adult patients across the continuum of care. Nutr Diet 66:S1-S34

72. National Institute for Health and Clinical Excellence (NICE) (2006) Nutrition support in adults: oral nutrition support, enteral tube feeding and parenteral nutrition (clinical guideline 32)

73. Jensen GL et al (2010) Adult starvation and disease-related malnutrition: a proposal for etiology-based diagnosis in the clinical practice setting from the International Consensus Guideline Committee. J Parenter Enteral Nutr 34(2):156-159

74. Rasmussen HH, Holst M, Kondrup J (2010) Measuring nutritional risk in hospitals. Clin Epidemiol 2:209-216

75. Michie S, van Stralen MM, West R (2011) The behaviour change wheel: a new method for characterising and designing behaviour change interventions. Implement Sci 6:42

76. French SD et al (2012) Developing theory-informed behaviour change interventions to implement evidence into practice: a systematic approach using the Theoretical Domains Framework. Implement Sci 7:38

77. Stevenson J et al (2018) Perspectives of healthcare providers on the nutritional management of patients on haemodialysis in Australia: an interview study. BMJ Open 8(3):e020023

78. Palecek EJ et al (2010) Comfort feeding only: a proposal to bring clarity to decision-making regarding difficulty with eating for persons with advanced dementia. J Am Geriatr Soc 58(3):580-584

79. Druml C et al (2016) ESPEN guideline on ethical aspects of artificial nutrition and hydration. Clin Nutr 35(3):545-556 
80. Mon AS, Pulle C, Bell J (2018) Development of an 'enteral tube feeding decision support tool' for hip fracture patients: a modified Delphi approach. Australas J Ageing 37(3):217-223

81. King PC et al (2019) "I wouldn't ever want it": a qualitative evaluation of patient and caregiver perceptions toward enteral tube feeding in hip fracture inpatients. J Parenter Enter Nutr 43(4):526-533

82. Greene GW et al (1999) Dietary applications of the stages of change model. J Am Diet Assoc 99(6):673-678

83. Prochaska JO, Velicer WF (1997) The transtheoretical model of health behavior change. Am J Health Promot 12(1):38-48

84. Wyers CE et al (2018) Efficacy of nutritional intervention in elderly after hip fracture: a multicenter randomized controlled trial. J Gerontol A Biol Sci Med Sci 73(10):1429-1437

85. Golden SD, Earp JA (2012) Social ecological approaches to individuals and their contexts: twenty years of health education \& behavior health promotion interventions. Health Educ Behav 39(3):364-372

86. Damschroder LJ et al (2009) Fostering implementation of health services research findings into practice: a consolidated framework for advancing implementation science. Implement Sci 4:50-50

87. Duncan DG et al (2006) Using dietetic assistants to improve the outcome of hip fracture: a randomised controlled trial of nutritional support in an acute trauma ward. Age Ageing 35(2): 148-153

88. Curtis K, Wiseman T (2008) Back to basics-essential nursing care in the ED: part one. Australas Emerg Nurs J 11(1):49-53

89. Antoniak AE, Greig CA (2017) The effect of combined resistance exercise training and vitamin D3 supplementation on musculoskeletal health and function in older adults: a systematic review and meta-analysis. BMJ Open 7(7):e014619

Open Access This book is licensed under the terms of the Creative Commons AttributionNonCommercial-NoDerivatives 4.0 International License (http://creativecommons.org/licenses/ by-nc-nd/4.0/), which permits any noncommercial use, sharing, distribution and reproduction in any medium or format, as long as you give appropriate credit to the original author(s) and the source, provide a link to the Creative Commons license and indicate if you modified the licensed material. You do not have permission under this license to share adapted material derived from this book or parts of it.

The images or other third party material in this book are included in the book's Creative Commons license, unless indicated otherwise in a credit line to the material. If material is not included in the book's Creative Commons license and your intended use is not permitted by statutory regulation or exceeds the permitted use, you will need to obtain permission directly from the copyright holder.

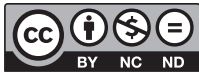

